\title{
Relevance of Tax Revenue Resources to Infrastructural Development of Nigeria
}

\author{
Oliver Ike Inyiama ${ }^{1}$, Edeh, Anthony Chinedu ${ }^{1}$, Chukwuani Victoria Nnenna $^{1}$ \\ ${ }^{l}$ Department of Accountancy Enugu State University of Science and Technology, Enugu State, Nigeria \\ *Corresponding Author: Oliver Ike Inyiama, Department of Accountancy Enugu State University of \\ Science and Technology, Enugu State, Nigeria
}

\begin{abstract}
The study examines the effect of Federal Government of Nigeria's Tax resources on infrastructural development of Nigeria. Income from Value Added Tax (VAT), Petroleum Profit Taxes (PPT) were used as proxies for Tax revenues/resources while Infrastructural Development was applied as proxy for Infrastructural Development of Nigeria. The research adopted ex-pos-facto research design as secondary data were used for the analysis. Data were sourced from the Central Bank of Nigeria Statistical Bulletin and the Federal Statistical Bureau. The study covered ten year period (2006-2015). Data were analyzed using the multiple linear regression technique. The result reveals tax revenue resources (PPT, CIT AND VAT) had positive and insignificant effect on Infrastructural Development in Nigeria. The study recommends that government should provide the necessary human and material infrastructures that are needed to support seamless tax collection so they can earn more income that will boost taxation to enhance infrastructural development in Nigeria.
\end{abstract}

Keywords: Infrastructure, Tax, Regression, Development, Resources.

\section{INTRODUCTION}

Suffice to say that Nigeria as a nation is currently undergoing recession with its attendant stresses. The situation has' most significantly brought about a drastic reduction in revenue accruable to the government especially from the oil and gas resources. Currently, there is a general fall in the price of crude oil which has adversely affected the Nigeria economic (Anyaehie and Areji, 2015; Uzonwanne, 2015). Former Minister of Finance Okonjo Iweala (2012) requests governments at various levels to look for other means of revenue generation for the sustainable economic development of Nigeria. To this effect, Kiabel and Nwokah (2009) note that the dwindling revenue and increased cost of running government require all tiers of Nigeria government to look for alternative means of improving their revenue base since it is obvious that the country's revenue from oil can no longer fully support its development objectives.

This scenario has got Nigeria thinking of other ways of diversifying its economy probably to cushion the effect of the unprecedented adverse changes. The reduction in the funds available to government has over the past years stifled its ability to meet up with the provisions of facilities (material, infrastructure and equipment) needed for productivity. The policy that is both employed a fiscal policy as well as income generating tool is widely employed by government in both developing and developed countries. The government at varying times decides on what level of taxes that can be imposed on the profits earned by petroleum outfits, instance and over the years in Nigeria, petroleum has been the main stay of the economy. The question is now whether government has earned enough taxes resources capable of supporting real growth of economic activities. Again, if it has, to what extent has that affected the economy of Nigeria using infra structural development or real sector needed for virile economy.

It is in the light of the above that this study has empirically examined the relevance of tax resources on economic growth in Nigeria using the infrastructural development.

Several arguments have trailed the relevance of taxation resources as a tool for enhancing infrastructural development' in Nigeria, Some -scholars submit that the quantum of tax resources collected over the years has not justified the level or in fact negates the level of infrastructural 
development in Nigeria. Some others also argue that the level of economic development have justified the quantum of taxes collected in Nigeria. Government in Nigeria is in recent times attaching keen interests in getting its citizens (individuals and corporate bodies) to brace up to the responsibilities of paying taxes. The Federal Inland Revenue Service has also developed a slogan saying that 'it pays to pay your tax'. Some studies submit that taxation positively and significantly affect economic growth in Nigeria. However, the World Bank Group (2014) submits that Nigeria had the lowest tax revenue when compared to its GDP.

Many citizens individuals and corporate have argue that tax resourced are not judiciously used and thereby deliberately ether evaded or even avoided tax. They often argue that the level of economic growth and development does not in any way justify the taxes revenues collected by government. This situation has often led government to lose a quantum of its revenue which would have been employed in growing the economy.

This study has therefore empirically seeks to empirically review the discordant submission by appraising the relevance of tax resources to infrastructural development in Nigeria and thus the reason for this study. The broad objective of this study is to appraise the relevance of tax resources on the infrastructural development in Nigeria. The specific objectives are to appraise the relevance of Value Added Tax Revenue, Petroleum tax, Companies Income Tax and Infrastructural Development in Nigeria.

\section{REVIEW OF RELATED LiterATURE}

\subsection{Conceptual Review}

\subsubsection{Concept of Taxation}

The concept of tax is old as civilization as any organized society has a need to embark on infrastructural development and the most available means of raising funds for the collective responsibilities of society is tax. Tax is a defined as compulsory levy imposed on a subject or upon his property by the government to provide security, social amenities and create conditions for the economic well-being of the society (Nwezeaku, 2012). According to Ezu and Okoh (2016), tax is a burden which every citizen must bear to sustain the government because the government has certain functions to perform for the benefits of those it governs. Integration of Taxation into the Neoclassical Growth Theory and Selected Ways of Tax Burden Approximation.

When evaluating the impact of fiscal variables on economic growth, it is necessary to derive from the fact that taxation influences economic growth solely through its impact on individual growth variables (Kotlan, Machova and Janickova, 2011). Growth theories can be considered as the key ones in this evaluation, and it is therefore necessary to introduce, at least in short, their substance and to describe the channels of taxation impact on the economic growth. The work of Solow (1956) and Swan (1956), or the neo- classical growth model can be considered to be the turning point within the researched resources of economic growth. However, from the long-term view and due to the de- creasing marginal product of capital, every economy aims towards the steady state in which it is not possible to increase output per one worker (Duczynski, 2003).

This research studied three types of tax resources namely: Value Added Tax, Petroleum Profit Tax and Company Income Tax.

\subsubsection{Concept of Value Added Tax as Revenue Resource}

Okpe (2000) defined VAT as a multistage tax imposed on the value added to goods and services as they proceed through various stage of production and distribution and to service as they are rendered which is eventually borne by the family consumer but collected at each stage of production and distribution chain. VAT was introduced in Nigeria as a consumption tax in 1994. It is 5\% charge on all consumption items classified as vatable items. Adereti, Sanni \& Adesina (2011) study also show that VAT revenue affect economic growth of Nigeria during the period 1994 to 2008.

\subsubsection{Concept of Petroleum Profit Tax as Revenue Resource}

According to Petroleum Profit Tax Act (1959) as amended, petroleum profit tax is a liability on petroleum profit arising where a company disposes off chargeable oil and gas. Disposal include delivery of chargeable oil to refinery, the tax is on the profit of the company from petroleum operation 
under the provision of PPTA in Nigeria. The petroleum operation as defined in the act, essentially involves petroleum exploration, development, production and sales of crude oil. Section 8, of Petroleum Profit Tax Act (PPTA) states that every company engaged in petroleum operation is under an obligation to render returns, together with annual audited account and computations, within a specified time after the end of it accounting period.

Petroleum profit tax is a tax applicable to upstream operations in the oil industry as it is related to rent, royalties, margin, oil mining prospecting and. exploration leases. It is the most important tax in Nigeria in terms of it share of total revenue, contributing over $70 \%$ of government revenue and $95 \%$ of foreign exchange earnings (Odusola, 2006). Okpe (2003) submits that petroleum profit is levied on the current year basis noting that the basis period for petroleum profit tax (PPT) is the actual profit of the accounting period. Thus, the basis period for any assessment year is the same as the accounting period of the company

\subsubsection{Concept of Company Income Tax as Revenue Resource}

Revenue resources derived by the imposition of taxes imposed on the profits companies. According to Nwankwo (2016) Company Income Tax is a form of tax levied by the federal government on the income and profits of companies. According to Ezu and Okoh (2016), Company Income Tax is levied on companies investing in Nigeria, Ezu and Okoh (2016) posits that CIT has positive and significant effect on GDP in Nigeria. This tax resource is dependent on the profits declared by companies. Government losses this taxes when a company declares loss.

\subsubsection{Infrastructural Development}

Infrastructural development is the aggregate of the facilities and social amenities which are provided to enhance the standard of living of the citizenry. The amenities could be in the form of pipe borne water, good roads, good educational facilities, befitting health care centres, qualified teachers and teaching facilities provided. According to Afuberoh and Okoye (2014), the primary economic goals of developing countries are to increase the rate of economic growth and hence per capita income, which leads to a higher standard of living.

\subsection{Theoretical Framework}

This study is anchored on the 'Benefit Theory' as propounded by Erik in 1919. The theory assumes that citizens tend to pay more taxes when they feel they have sufficient benefits from the activities of the state. It is however argued that the services which are provided are not quantified and measured after all some citizens who pay taxes do not have the opportunity of enjoying them. This theory is relevant to this study as it evaluate the benefits of tax just as measured by the capital infrastructure provided by the state.

\subsection{Empirical Review}

Some empirical studies which have been done on related topics are hereby reviewed as follows:

\subsubsection{Relevance of Value Added Tax on Infrastructural Development in Nigeria}

Adereti, Sanni and Adesina (2011), uses time series data to study the effect of Value Added Tax on the Gross Domestic Product (GDP). Total Tax Revenue and Total (Federal Government) Revenue from $1 \% 4$ to 2008. Findings showed that the ratio of VAT Revenue to GNP averaged $1.3 \%$ compared to $45 \%$ in Indonesia, though VAT Revenue accounts for as much as $75 \%$ significant variations in GNP in Nigeria.

Nwosu and Okafor(2014) examined the relationship between both total revenue and disaggregated expenditure in Nigeria. The study used a times series data ranging from (19702011). The V AR results indicate that total government expenditure, capital and recurrent expenditures have long run unidirectional relationships with total revenue.

Ejiofor and Ekwe (2016) in their study titled 'Appraisal of Contributions of the various sources of local governments' revenue to the economic development of Nigeria (1993-20 13). Findings indicate that the prevalent crash in crude oil prices will adversely affect federal intensive effort towards effectively harnessing and strategically diversifying the internal generated revenue sources.

Aeesh and Sheikha(2015) in their study titled 'the role of tax revenue in addressing the budget deficit in Iraq. Secondary data were used as the actual tax revenues were used to calculate the actual gap the 
that it has helped to fill in the budget 2004-2012. The tax indicators were shown. The study shows that there exists untapped tax energy in Iraq.

\subsubsection{Relevance of Petroleum Profit Tax to Infrastructural Development in Nigeria}

Abdul-Rahamoh, Taiwo and Adejare (2013) appraised the effect of petroleum profit tax on Nigeria Economy. The study covered a forty, year period from (1970 to 2010). Analysis was done using multiple regression. Regression analysis using SPSS version 17 was employed by the researchers in testing specific objectives statements. The study revealed that taxation has a significant contribution on Gross Domestic Product (GDP). The study indicates. that petroleum profit tax had significant impact on Nigerian economy.

Olatunji and Adegbite, (2014), studied the effect of petroleum profit tax interest Rate and Money Supply on Nigeria Economy from 1970 to 2010; multiple regression were employed to analyze the relationship among variable. The analysis revealed that short run effect of petroleum profit tax was positive while that of interest rate was positive on economic growth. The study indicate that petroleum contribute positively to income.

Eyisi, Oleka and Bassey, (2015) appraised the effect of taxation on macro-economic performance in Nigeria from 2002 to 2011 using ordinary least square regression method. Result obtained show that government earnings from taxation has positive and significant effect on real gross domestic product in Nigeria, government revenue from taxation has negative significant influence on unemployment rate in Nigeria.

Ezu and Okoh (2016).Effect of Tax revenue on selected macro-economic variables in Nigeria(20002015). This study was secondary data. Total tax revenue from Personal Income Tax, Company Income Tax and Consumption Tax had negative but insignificant effect on inflation. Exchange rate, money supply and interest rate have positive effect on inflation.

\subsubsection{Effect of Company Income Tax on Infrastructural Development in Nigeria.}

Oziengbe (2013) explores the relative impacts of federal capital and recurrent expenditures on Nigeria's economy in the 1980-2011 period. The empirical analysis begins with an investigation of the effect of total government expenditure on gross domestic product (GDP) using multiple linear regression analysis. The variance decomposition results indicate that the proportion of forecast error variance of GDP explained by innovations in RECEXP dominates the proportion explained by innovations in CAPEXP in all the periods.

Nwofor and Gordon (2013) studied tax revenue and government expenditure. They explored how revenue generated from taxation affects Nigeria expenditure. Secondary data used for data collection hypotheses and hypotheses tested using Pearson moments collation coefficient. The study found out that the volume of expenditure incurred $\mathrm{S}$ by government can negatively affect total tax revenue especially those when those expenditure are mainly a recurrent expenditure.

Ezu and Okoh (2016) while writing on the effect of tax revenue on selected macro-economic variables in Nigeria (2000-2QI5). Findings revealed that increase in economic growth. Study showed that total tax revenue and consumption and property tax had positive but insignificant effect on GDP. Company Income Tax has positive and significant effect on GDP. Personal Income Tax has insignificant negative effect on GDP. Total tax revenue has no significant effect on GDP. Total tax revenue from Personal Income Tax, Company Income Tax and Consumption Tax had negative but insignificant effect on inflation. Exchange rate, money supply and interest rate have positive effect on inflation.

\section{Methodology}

The study adopted the ex-post facto research design as data for the study are already existing/ established data. The population is one as Nigeria is considered as an entity. The study sample size is equivalent to its population as Nigeria is still taken as an entity. Data for this study is secondary data and were sourced from relevant documentations of the federal government namely the statistical bulletin of the Central Bank of Nigeria and National Bureau of Statistics. The data for this study covered a period often years (2006-2015).

The independent variable of the study is tax revenue resources measured by Value Added Tax(VAT), Petroleum Profit Tax(PPT) and Company Income Tax.(CIT). The dependent variable of this study is infrastructural development represented by capital expenditure of the federal government. Multiple 
Linear Regression technique was used to analyze the data. The following econometric models are adopted in this study. The models applied were adopted by similar studies in the past such as such as Inyiama and Ogboji (2016), Ofoegbu and Akwu (2016), Inyiama and Nwankwo (2016).

\section{Model Specification}

Cap EXP= f(PPT, VAT, CIT)

The study was evaluated using three different models. Model for Value Added Tax

Model 3 will be used to test the effect of Value Added Tax on GDP (Hypothesis Two). Thus:

Thus:

$\mathrm{INFDVT}=. \mathrm{B} \mathrm{J}+\mathrm{B} 2 \mathrm{Ln}$ VAT $+\mathrm{E}[$

Where:

INFD VT=. = Infrastructural' Development

B $1=$ Constant

VAT $=$ Value Added Tax

Et $\quad=$ Statistical Error Level in year $\mathrm{t}$

Model for Petroleum Profit Tax

Model 2 will be used to evaluate the effect of PPT on GDP (Hypothesis One). Thus:

INFDVT $=.=B j+B 2 P P T+E t$

Where:

INFD VT $=.=$ Infrastructural. Development

B $1=$ Constant

$\mathrm{PPT}=$ Petroleum Profit Tax

Et $\quad .=$ Statistical Error Level in year $\mathrm{t}$

Model for Company Income Tax and Infrastructural Development

Model 4 will be used to test the effect of Value Added $\mathrm{T}<$; l.x on Infrastructural Development (Hypothesis Three ).

Thus:

INFDVT $=.=\mathrm{B}]+2 \mathrm{C} 1 \mathrm{~T}+\mathrm{Et}$

Where:

INFDVT $=.=$ Infrastructural Development

$\mathrm{Bl}=$ Constant

CIT = Company Income Tax

Et $\quad=$ Statistical Error Level in year $\mathrm{t}$

\section{DisCuSSION OF RESULTS}

\subsection{Data Presentation (See Appendix)}

\subsection{Data Analysis}

The hypotheses were tested and analyzed using the Ordinary Linear Multiple Regression.

4.2.1. Test of Hypothesis One

Ho: Value Added Tax Revenue Resources has no significant effect on Infrastructural Development in Nigeria.

Decision Rule: Accept Ho if p-value > 0.05, otherwise reject Ho

Table1. Regression result showing the relevance of VAT resources to Infrastructural Development in Nigeria

\begin{tabular}{|c|l|l|c|c|c|}
\hline Modell & R & R Square & Adjusted R Square & Coefficient & Probability \\
\hline & 0.371281069 & 0.137849 & 0.03008 & 0.30141 & 0.290824 \\
\hline
\end{tabular}

Source: Author's Computation, 2017

Level of Significance at $5 \%$ 
Table 1.0 shows the regression result explaining the relevance of Value Added Tax resources to Infrastructural Development (INFDVT) in Nigeria. The analysis shows an R Square of $13.78 \%$. This means that $14 \%$ of the variations in INFDVT could be explained by changes in Value Added Tax (VAT). Again, a unit increase in VAT will cause an increase of 0.30141 in INFDVT. The result shows a p-value of 0.290824 . This means that the effect of VAT on INFDVT is positive and insignificant at $5 \%$ level of significance.

Decision: Based on the result, Ho is accepted.

\subsubsection{Test of Hypothesis Two}

Ho: Petroleum Profit Tax Revenue Resource has no significant effect on Infrastructural Development (INFDVT) in Nigeria.

Decision Rule: Accept Ho if p-value > 0.05, otherwise reject Ho

Table2. Regression result showing the effect of PPT Revenue Resource on INFDVT in Nigeria

\begin{tabular}{|c|l|c|c|c|c|}
\hline Model 2 & R & R Square & Adjusted R Square & Beta Coefficient & Probability \\
\hline & 0.11068 & 0.01225 & -0.1112 & 0.02083 & 0.7608 \\
\hline
\end{tabular}

Source: Author's Computation, 2017

Level of significant at $5 \%$

Table 2 shows the regression result of the test showing the effect of Petroleum Profit Tax (PPT) on Infrastructural Development (INFDVT) in Nigeria. The analysis shows R Square of 0.01225.This means that $1 \%$ of the variations in Infrastructural Development is accounted by the Petroleum Profit Tax (PPT). A unit increase in PPT will cause an increase of 0.02083 in Infrastructural Development Again; the result shows a p-value of 0.7608 shows that the effect of PPT on Infrastructural Development is positive and insignificant at $5 \%$ level of significance.

Decision: To this extent of the result above, Ho is accepted while the alternate is rejected.

\subsubsection{Test of Hypothesis Three}

Ho: Company Income Tax Revenue Resources has no significant effect on Infrastructural Development (INFDVT) in Nigeria.

Decision Rule: Accept Ho if p-value > 0.05, otherwise reject Ho

Table3. Regression result showing the effect of $V$ AT on Infrastructural Development (INFDVT) in Nigeria

\begin{tabular}{|l|l|c|c|c|c|}
\hline Model 3 & R & R Square & Adjusted R Square & Beta Coefficient & Probability \\
\hline & 0.3111 & 0.0968 & -0.0161 & 0.1762 & 0.3816 \\
\hline
\end{tabular}

Source: Author's Computation, 2017

Level of Significance at $5 \%$

Table 3 shows the regression result explaining the effect of Company Income Tax (CIT) on 'Infrastructural Development (INFDVT) in Nigeria. The analysis shows R Square of $10 \%$. This means that about $10 \%$ of the variations in INFDVT is accounted for by the variations in Company Income Tax (CIT). A unit increase in CIT resource will cause an increase of 0.1762 in INFDVT. The result shows a p-value of 0.3816 which is less than $5 \%$. This means that the effect of CIT on INFDVT is positive and insignificant at $5 \%$ level of significance.

Decision: To the extent of the above result, Ho is accepted while the Hi is rejected.

\section{CONCLUSION}

\subsection{Summary of Findings}

The following findings emanated from the study:

a) Value Added Tax Revenue Resource has insignificant relevance on Infrastructural Development in Nigeria.

b) Petroleum Profit Tax Resource is insignificantly relevant to Infrastructural Development in Nigeria. 
c) Company Income Tax Resource has insignificant relevance on Infrastructural Development in Nigeria.

\subsection{Conclusion}

In line with the above findings, the study concludes that Taxation as defined by the proxies studied has positive and insignificant relevance on the Infrastructural Development (INFDVT) in Nigeria. Since, taxation is a veritable tool for economic and social emancipation, government should articulate and implement better policies that can enhance the effect it has on Infrastructural Development INFDVT in Nigeria.

\section{RECOMMENDATIONS}

This research has made the following recommendations:

a) Policies to be put in place to effectively re-position Value Added Tax to enhance its effect on infrastructural development in Nigeria.

b) The petroleum sector in Nigeria should be well coordinated and encouraged to grow so that more revenue should accrue to it. It is hoped that increased income through petroleum 'will enhance tax payment from that sector.

c) Companies should be encouraged to pay CIT through provision of supporting infrastructure, as this will help them make more profit that could enhance tax payments.

\section{REFERENCES}

[1] Abdul-Rahamoh, F.H., Taiwo \& Adejare, AT.(2013). Analysis of the effect petroleum tax on Nigeria economy. Asia Journal of Humanities and Social Sciences, 1(1),1-12

[2] Adams, W.T.(2012). Effect of total revenue on macro-economic variables. American Academy of Financial Management, 8(3), 56-78.

[3] Adereti, S.A, Sanni, M.R.\& Adesina, J.A (2011). Value added tax and economic growth of Nigeria, European Journal of Humanities and Social Sciences, 10(1), 456-471.

[4] Aeesh, M.O. \& Sheikha, S.N. (2015). The role of tax revenue in addressing the budget deficit . in Iraq. European Journal of Accounting, Auditing and Finance Research. 3(5)55-63.

[5] Aguolu G.C.(2011). The relationship between tax and macro-economic variables in Nigeria, Journal ofEconomics,3(5), 409-421.

[6] Adegbie, F.F. \& AS. Fakile, (2011).Company income tax and Nigeria economic development. European Journal of Social Sciences, 22(2): 309 - 332.

[7] Arowoshegbe \& Uniamikogbo, (2016). Effect of tax revenue on economic development. Research Journal of Financial Sustainability Reporting 1(1) 47-55

[8] Dackehag, M. \& Hansson, A (2012). Taxation of income and economic growth: An empirical analysis of 25 Rich OECD Countries. Lund University Department of Economics. Working PaperNo. 2012:6. Accessed online

[9] Ejiofor, C.J. \& Ekwe, M.C. (2016). Appraisal of contributions of the various sources of local governments' revenue to the economic development of Nigeria.(1993-2013). A paper presented at the Nnamdi Azikiwe University, Awka, Faculty of Management Sciences International Conference, 8-10 Nov. 2014.

[10] Ezu, G. K \& Okoh, J.I. (2016). Effect of tax revenue on selected macro-economic variables in Nigeria (2000-2015). A paper presented at the 2016 International Conference of the Management Sciences of the Nnamdi Azikiwe University, Awka, Anambra State, Nigeria held 8-10th Nov.

[11] Inyiama, 0. 1. \& Nwankwo, B.(2016). Effect of taxation on economic growth of Nigeria. Research Journal of Financial Sustainability Reporting 1 (1) 109-124

[12] Inyiama,O.I \& Ogboji, A (2016). Evaluation of the effect of non-oil tax revenue on economic growth of Nigeria. Research Journal of Financial Sustainability Reporting 1(1) 56-67

[13] Ofoegbu, G.N, David, O. Akwu, O.(2016).Empirical analysis of effect of tax revenue on economic development of Nigeria. International Journal of Asian Social Science, 6(10): 604613, www.aessweb.com. Retrieved 22/12/16

[14] Okpe, 1.1. (2003). Petroleum profit tax in Nigeria. Enugu: Joe Best Books

[15] Okoye, J, \& Gbegi, D.O. \{2013). Effective Value Added Tax. An imperative for wealth Creation in Nigeria, Global Journals Inc. 13:

[16] Okafor, H.O (2014). Government revenue and expenditure in Nigeria. A disagravated analysis. Asian Financial Journal. 4(7)877-892. 
[17] Nnaji, K.C. (2016). Effect of Petroleum Profit Tax on Economic development of Nigeria. A project submitted to Department of Accountancy, Enugu State University of Science and Technology.

[18] Oziengbe, S.A. (2013). The relative impacts of federal capital and recurrent Expenditures on Nigeria's economy (1980-2011). American Journal of Economics, 3(5): 210-221 Accessed DOl: 10.5923/ j.econo mics.20130305.02

[19] World Bank Group (2014) report on African's tax revenue as a percentage of Gross Domestic Product, 2009-2012.

[20] World, C.N. and Emeka, N. (2012). Tax revenue and economic development in Nigeria: A macroeconometric approach. Academic Journal of Interdisciplinary Studies, 1 (2): 211-223.

\section{APPENDIX}

\section{- Variables}

\begin{tabular}{|c|c|c|c|c|c|}
\hline Year & $\begin{array}{c}\text { Capital Expenditure } \\
\mathbf{N}^{\prime}\end{array}$ & VAT N' & $\begin{array}{c}\text { PPT } \\
\mathbf{N}^{\prime}\end{array}$ & $\begin{array}{c}\text { CIT } \\
\mathbf{N}^{\prime}\end{array}$ & $\begin{array}{c}\text { Total Tax Resources } \\
\mathbf{N}^{\prime}\end{array}$ \\
\hline 2015 & 829000000 & 823870000 & 2678430290 & 915520000 & 4417820290 \\
\hline 2014 & 783100000 & 794200000 & 2453950000 & 1207300000 & 4455450000 \\
\hline 2013 & 1108400000 & 795600000 & 2666340000 & 985500000 & 4447440000 \\
\hline 2012 & 874700000 & 710200000 & 234230000 & 848600000 & 1793030000 \\
\hline 2011 & 918548290 & 649500000 & 3070590000 & 700500000 & 4420590000 \\
\hline 2010 & 883870000 & 562900000 & 1480360000 & 657300000 & 2700560000 \\
\hline 2009 & 1152796500 & 481400000 & 934400000 & 600600000 & 2016400000 \\
\hline 2008 & 960890010 & 401700000 & 2060700000 & 420600000 & 2883000000 \\
\hline 2007 & 759281200 & 312600000 & 1132000000 & 332400000 & 1777000000 \\
\hline 2006 & 552358800 & 232700000 & 1352200000 & 246700000 & 1831600000 \\
\hline
\end{tabular}

Source: Central Bank of Nigeria Statistical Bulletin

Citation: Oliver Ike, Inyiama et al. "Relevance of Tax Revenue Resources to Infrastructural Development of Nigeria." International Journal of Managerial Studies and Research (IJMSR), vol 5, no. 10, 2017, pp. 74-81. doi:http://dx.doi.org/10.20431/2349-0349.0510007.

Copyright: () 2017 Authors. This is an open-access article distributed under the terms of the Creative Commons Attribution License, which permits unrestricted use, distribution, and reproduction in any medium, provided the original author and source are credited. 